\title{
A QUIZZICAL LOOK AT AUTHORS OF NEW JERSEY
}

\author{
BY RUDOLF KIRK
}

PROFESSOR KIRK, former editor of the Journal, has garnered, while compiling a check list of New Jersey authors, some interesting facts about the local associations of famous writers who have lived and written in the State.

Do you know-?

I. What author of New Jersey was president of Princeton for one month?

2. What author of New Jersey writes notable critical essays for The New Yorker?

3. What author of New Jersey was carried away from the State at the age of fourteen months?

4. What author of New Jersey was "The Poet of the Revolution"?

5. What author of New Jersey was "flunked out" of Princeton?

6. What author of New Jersey lived on Mickle Street, Camden?

7. What author of New Jersey has an Army camp named after him?

8. What author of New Jersey became President of the United States?

9. What author of New Jersey reported the Spanish-American War?

Io. What author of New Jersey was a famous fisherman?

I I. What author of New Jersey signed the Declaration of Independence?

I 2. What author of New Jersey wrote a book on General Grant which was recently well reviewed in The New York Times?

I 3. What poet of New Jersey is also a physician?

I4. What author of New Jersey has made famous "Pilgrimages" into American literature?

I 5. What author of New Jersey is known as "The Gentleman from Indiana"?

16. What critic-professor of New Jersey was once editor of The Nation?

I 7. What writers on the Rutgers faculty are known for their poetry and criticism? 
Now that you have tossed off those I 7 questions, you may be ready for two more difficult ones: First, what is an author? Second, what is a Jerseyite?

Why not answer these two questions in one sentence and say that a Jersey author is a man or woman who lives and writes in New Jersey? Surely that is easy, but perhaps it is not satisfactory. What about an author who is removed from the State by his parents when he is a baby child? Is he a Jerseyite? Or what of one who takes up residence in the State just in time to die here? Or one who goes to college here while all the time a resident of another state to which he returns upon graduation? Or one who comes for a month at the Shore to get "atmosphere" for his new novel about the Revolution! These are extreme cases, but the student finds all of them illustrated in the lists of authors claimed by or for New Jersey.

If we approach the other part of the problem, what is an author, what shall we say of the writers of cookbooks? Or the compilers of quotations? Or the editors of anthologies? If one sets about making a list of Authors of New Jersey, what should be one's attitude towards such writers? Then what about journalists who contribute their signed articles to the papers of New Jersey every day of the year? Many of these men and women are extremely fine writers, and it would seem that they ought to be listed if one sets about the project of collecting the names and dates of the Authors of New Jersey.

All of these questions came to mind when the present writer was asked to compile biographical data on the Authors of New Jersey as a project sponsored jointly by the New Jersey Association of Teachers of English and the Department of English of Rutgers University. Immediately he called on his wife for assistance, and they set to work to gather data from books, folders of newspaper clippings, and whatever other sources came to hand. Then definitions became necessary, for, though the lists of New Jersey writers found in standard volumes and the clippings which local libraries have cut from their home-town papers furnished invaluable records of Jersey men and women who have distinguished themselves by their pens, all too often the avalanche of names was not supported by titles of books which seemed appropriate for the purposes of the sponsoring groups.

To begin with, the teachers of English are primarily interested 
in literary productions. They are not concerned with scientific, political, or philosophical treatises, unless these happen to be of a clearly literary nature. Nor are they interested in purely journalistic effusions such as appear in our newspapers and magazines. Indeed, we have made the rule that no author will be listed who has not had a separately published book. Another group to be omitted is the band of textbook writers-which leaves us with the problem of what to do with the scholars of Rutgers and Princeton! Happily for us, we are merely the compilers of an initial Checklist. If from this beginning a book on Authors of New Jersey finally emerges, the decisions as to "permanent literary value" will be made by the editorial board of that study.

Our policy, then, has been to list those Jersey men and women who have lived a significant portion of their lives in New Jersey and who appear to have literary distinction. Just what is "a significant portion" of one's life has to be left to the patriotic zeal of claimants, the judgment of editors, and even the vagaries of chance. In practice if we found in a library local newspaper clippings celebrating the literary triumph of a favorite son or daughter, we added the name to our Checklist without much searching of evidence for native roots. While omitting in most instances the writers of sermons, speeches, children's books, scientific, political, and historical works, newspaper editorials or articles, and textbooks, we have included authors of separately published books of poetry, drama, essays, fiction, and prose works of distinction.

Out of the nine hundred and more authors on our present Checklist, which ones stand out? Perhaps a few names from Colonial times to recent days will serve to remind us of our literary heritage.

Though not the earliest poet of the State, Philip Freneau (I $752-$ I 832) is the first poet to be remembered both here and throughout the Nation, for he won the title "Poet of the Revolution" by his spirited satires against King George the Third and by many other attacks on the British during those years when our independence was at stake. A graduate of Princeton in the Class of I 77 I, Freneau early took his stand on the side of liberty and wrote both in verse and prose in its defence, but his works in this great cause are not today the ones by which he is remembered. We love more The Wild Honeysuckle and The Indian Burying Ground which tell of our native traditions. 
We catch a glimpse of New Jersey landscape as we stand with the poet on Pine Hill, Monmouth County, and hear his lines from Ode On a remote Perspective view of Princeton College:

Where Millstone's stream, in swampy Groves

Collects its limpid rills,

And where the infant current roves

Amidst its parent hills,

The Hill of pines exalts its head, And towering near the River's bed,

Gives many a distant sky-topt view

In coloured heights of misty blue

In wild disorder spread.

On this one hundredth anniversary of the publication of the first edition of Leaves of Grass, we are glad to recall that Walt Whitman ( 8 19-1892) lived for the last nineteen years of his life in a house on Mickle Street, Camden. Here it was that he added many portions to Leaves of Grass and wrote Specimen Days and November Boughs. Something of the spirit of the Jersey coast comes to the reader of "Patroling Barnegat":

Wild, wild the storm, and the sea high running,

Steady the roar of the gale, with incessant undertone muttering,

Shouts of demonic laughter fitfully piercing and pealing,

Waves, air, midnight, their savagest trinity lashing,

Out in the shadows their milk-white combs careering,

On beachy slush and sand spirts of snow fierce slanting,

Where through the murk the easterly death-wind breasting,

Through cutting swirl and spray watchful and firm advancing,

(That in the distance! is that a wreck? is the red signal flaring?)

Slush and sand of the beach tireless till daylight wending,

Steadily, slowly, through hoarse roar never remitting.

Along the midnight edge by those milk-white combs careering,

A group of dim, weird forms, struggling, the night confronting,

That savage trinity warily watching.

Whitman has always been a controversial figure in our literature, but he has steadily gained ground in critical estimation during the past century, and today he stands as one of the greatest of the moderns. Though New Jersey added little obvious local color to Whitman's poetry, his association with Camden gives the State a solid claim to him as a New Jersey author. 
Another writer whom the most advanced of the moderns regard as one of their own is Stephen Crane (187I-1900), a native of Newark, all of whose important work was published within the space of seven years, before his death from typhoid fever. Maggie came first in I 893. Drawn from Crane's own experience and observation in the Bowery of New York City, it was, as Crane said, "too honest" for a regular publisher to bring out and had to be printed privately at Crane's expense with money which the author borrowed from his brother. Not until The Red Badge of Courage (1896) swept the country did Maggie sell. In these novels, in such extraordinary short stories as The Open Boat, and in some of his wonderfully penetrating poems, Crane suggested to modern writers how they might tell their stories of present-day life. New Jersey may be proud to have fostered this genius, who began life as a journalist and later reported the Spanish-American War.

Dr. William Carlos Williams (born 1883), whom President R. C. Clothier once called "The Poet Laureate of New Jersey," sturdily continues the great tradition of the physician-poet. His Paterson, published in four parts, perhaps best illustrates that type of poetry written about a particular locale. In the opening lines we find the spirit of the myth-making twentieth century poet as he attaches to his own city a story of its origin:

Paterson lies in the valley under the Passaic Falls its spent water forming the outline of his back. He lies on his right side, head near the thunder of the waters filling his dreams! Eternally asleep, his dreams walk about the city where he persists incognito. Butterflies settle on his stone ear.

Immortal he neither moves nor rouses and is seldom seen, though he breathes and the subtleties of his machinations drawing their substance from the noise of the pouring river animate a thousand automatons.

A last author whom we shall mention is Edmund Wilson, (born I 895), a native of Red Bank, still living and still writing with his remarkable critical insight. A graduate of Princeton in the Class of I9I6, he has edited Vanity Fair and worked on the staff of The New Republic. Within the last two or three years he has studied Hebrew at the Princeton Theological Seminary and has contributed to The New Yorker several important long articles in the field of 
Biblical criticism. He is best known, however, for his books, Axel's Castle, Memoirs of Hecate County, and others.

Since time and space do not permit longer accounts of individual Authors of New Jersey, we have spoken of only a few writers whose places among American men of letters can hardly be disputed. Others, too, might be added-Jonathan Edwards, who lived in New Jersey as President of Princeton one month; John Witherspoon, who was the only clergyman to sign the Declaration of Independence; Woodrow Wilson, who became President of the United States; James Fenimore Cooper, who was taken out of New Jersey by his parents at the age of fourteen months, but still is claimed by the ardent for our State; Frank R. Stockton, who, though born in Philadelphia, lived most of his life in Rutherford, Morristown, and Madison; F. Scott Fitzgerald, who was one of the most distinguished authors ever "flunked out" of Princeton; Booth Tarkington, who in spite of a Princeton bachelor's degree, remains The Gentleman from Indiana; Joyce Kilmer, for whom Camp Kilmer was named; Henry Van Dyke, fisherman and essayist, whose graceful writing has charmed millions; Paul Elmer More, many of whose critical essays may be found in past issues of The Nation. We must not forget such living celebrities as Mr. Van Wyck Brooks, a native of Plainfield, whose "Pilgrimages" have led many of us to enjoy The Flowering of New England; and Mr. Earl Schenck Miers, whose recent book on General Grant before Vicksburg is his latest study of the War Between the States. Nor must we fail to mention four Rutgers professors, whose contributions to poetry and criticism are constantly bringing distinction to our State University: the lyrics of Professor Horace E. Hamilton, collected in such a volume as Through the Moon Gate, give us a delightful picture of Chinese life as the son of a medical missionary knew it; the poems of Professor John Ciardi appear in most of the leading literary periodicals of the country; Dante's Drama of the Mind by Professor Francis Fergusson brought its author the Christian Gauss Award of Phi Beta Kappa Society in I 953; and the books of Professor Houston Peterson, better known at home as brilliant teacher and toastmaster, have won fame for him and for Rutgers throughout the country.

Some nine hundred other names might be listed, and many hundred more will be brought to light by future researchers into the literary treasures of our State. 